Philosophy and Progress: Vols. LXI-LXII, January-June, July-December, 2017 ISSN 1607-2278 (Print), DOI : https://doi.org/10.3329/pp.v61i1-2.44200

\section{KARL MARX'S PHILOSOPHY AND ITS RELEVANCE TODAY}

\section{Haroon Rashid}

\section{Introduction}

How do we see the world? What is the way of looking at the world? In other words, how do we explain the problems of our life and the world we live in? This is what philosophy does, i.e., philosophy is a way of explaining life and the world. More precisely, philosophy is an outlook of the fundamental problems of life and the world. A philosopher starts his thinking with the exercise of rationality. He makes a rational investigation of the problems with which he is concerned. In this sense, philosophy is a rational outlook of the fundamental problems of life and the world. A philosopher is a rational and critical thinker and in this way of thinking he formulates his ideas and builds theories about life and the world. In this sense, philosophy is mainly a theoretical activity and a philosopher is concerned with conceptual or theoretical activity. This is the traditional way of defining philosophy.

\footnotetext{
* Professor, Department of Philosophy, University of Dhaka E-mail : haroonrashid57du@gmail.com
}

It was Karl Marx, a philosopher as well as a revolutionist (a philosopher of revolution), who had broken this tradition of philosophy and provided an alternative definition of philosophy. The function of philosophy, according to him, is not only to explain the world but also to change it. Philosophy is not only confined with theoretical activity, it is also concerned with practical issues and problems of life. Hence philosophy is both a theory and a practice. As a theory it explains the basic concepts, and as a practice it applies these concepts to practical life. Theory and practice, for Marx, are inseparably connected, one cannot be isolated from the other. They are two aspects of the same reality (objective reality). While traditional philosophers found theory as isolated from practice and emphasized more on theory than on practice, Marx attempted to make a synthesis between theory and practice. That does not mean that Marx rejected theoretical activity as an important aspect of understanding the world. What he wanted to say is that the function of theory is to provide general idea about man's practical activity, to discover the general nature of the world and to play a supportive role in changing the world. However, no theory independently, i.e. apart from practice can play the role in changing the objective world. It can do this job only in close association with practice. Here lies the relation between theory and practice. Marx was the first philosopher who clearly showed this relation and combined theory with practice.

I argue that a fair reading of Marx will show that he had brought about an epistemological break in the history of philosophy. In other words, Marx had brought about a revolution in human thought, particularly in the history of philosophical thoughts. He had fundamentally changed the way of how we explain the problems of our life and the world. According to Marx, philosophy is not a pure theoretical 
activity, it is not an abstract thought isolated from concrete social life; rather it is inseparably connected with social reality. Concrete life process of concrete man is the basis of philosophy. That is to say, practical activity of practical life is the basis of philosophy. In this sense, philosophy is practical, i.e., philosophy not only explains social life but also paves the way of changing it.

\section{Why to Read Marx Today}

'What is living and what is dead in the thoughts of Hegel'? This was the question asked by the Italian philosopher Benedetto Croce in 1907. The same question has been asked about Marx for the last few decades. In 1985 Jon Elster, an Anglo-American analytical Marxist, wrote an article entitled "What is Living and What is Dead in the Philosophy of Karl Marx"? Later in his semminal book Making Sense of Marx ${ }^{1}$, Elster shows that Marxism is meaningful (living) today from the normative (moral) perspective. Marx died one hundred and thirty five years age (on 14 March 1883). Since then so much has happened. Marxist regimes, i.e., socialist society based on Marxist philosophy has failed. The collapse of Soviet socialism or the fall of the Berlin Wall has often taken to be the fall of Marxism (that is, Marxism as a dead philosophy). If so, then what is the point of reading Marx today?

The first and the most important point of reading and belonging to Marx's thought is that 'he was one of a handful of thinkers who have fundamentally changed the way we see the world. In this he ranks with Plato, Aristotle, Copernicus, Galileo, Newton, Darwin, Freud and Einstein,' Marx formulated his philosophy in The German Ideology ${ }^{2}$ as the materialist conception of history' (historical materialism). This can be considered to be a scientific philosophy which provides a scientific (practical) interpretation of history. Marx will forever be remembered for this powerful tool of explaining the history of human society. That is why we bear the legacy of his philosophy, we cannot but belong to his scientific thought and read it to get a clear understanding of the world. Marx derived his materialist philosophy from the 'simple fact of history' that 'mankind must first of all eat, drink, have shelter and clothing, before it can pursue politics, science, art , religion, etc'. Marx's materialist conception of history is so powerful that even his critics and opponents cannot ignore it, said Marx's lifelong collaborator Friedrich Engels at his graveside.

Marx is not only a philosopher but also a revolutionist at the same time. He is a philosopher in the sense that he provided a materialist interpretation of history. He is a revolutionist in the sense that he applied his philosophy to change history, i.e., to pave the way for creating a new chapter of history for mankind. Marx is a burning example of how a philosopher has been turned into a revolutionist. He not only made a theoretical investigation of why revolution happens but himself also participated in revolutionary activities to create new chapter of human history (new human society). Theory is, for him, not only a means to understand the world around him, but also a step to transforming that world.

Understanding Marx's thought is essential for anyone who considers himself to be a socialist, who seeks for the selfemancipation of the working class and who wishes to do away with the exploitation built into the capitalist system. Unfortunately, understanding Marx is not always as simple as it should be. This is not mainly because his writings are obscure, he is, on the whole, a clear writer. The main difficulty is that Marx's ideas have the most enormous distortion. ${ }^{4}$ This harm has been done partly by his enemies, by the defenders of the existing capitalist system and partly by his dogmatic 
followers. So many lies have been written about Marx by his enemies. He has been called many things-fanatic, anti-semite, forerunner of Hitler (although he was an internationalist) and even a 'fundamentally religious' thinker (Marx was a life long atheist!) These calumnies are, however, comparatively easy to refute. But more difficult to deal with the distortions that Marx's thought has suffered at the hands of his followers. Marx said towards the and of his life-"All I know is that I am no Marxist, God save me from my friends!,

The other source of distortion is the fact that Marx has been discovered by the academics. A new species of Marxism has arisen in the universities whose aim is not to overthrow capitalism, but to study Marxism itself. 'Western Marxism' is the polite name for this species, since its members are found mainly in Western Europe and north America. However, 'Academic Marxism' would be a more accurate name for this species. ${ }^{6}$

\section{Philosophical Legacy of Marx}

Marxism, from its very emergence, raises enormous controversies which results to different trends like Classical Marxism, Western Marxism, Analytical Marxism, Normative Marxism etc. and various sorts of confusions arise from it. Particularly, there remains a controversy as to the question whether Marxism can be called a philosophy. Marxism does not suggest any definite theory, it deals with different aspects of man and society and discovers different theories concerning society, economics, politics, history etc. However, all these theories have their foundation on philosophy. So, to understand Marxism as a whole, first of all, we have to understand its philosophical foundation. A general objection against Marxism is that it emphasizes more on economis rather than on philosophy, and as a consequence it culminates in economic determinism. Great philosopher like Bertrand Russell ${ }^{7}$ says that historical materialism is more an economic theory than a philosophical one. I think that this sort of objection is due to misreading and misunderstanding of Marx's thought. Marx is not a philosopher in the traditional sense, he is not a philosopher like Russell or other traditional philosophers; rather he is a philosopher in a different sense. Now, this is our job to look for such a philosophy to understand the philosophical legacy of Marx.

A unique feature of Marx's philosophy is that he did not start his thought with a straightforward philosophical issues like ontology or epistemology or ethics (as the traditional philosophers use to do). He started his philosophical thought with the critique of traditional philosophers. So, to get a clear understanding of his philosophy, we need to have a fair reading of his critique of traditional philosophy. Marx's philosophical thought becomes evident in his last “Thesis on Feuerbach': 'Philosophers have interpreted the world in various ways, however, the point is to change it' ${ }^{8}$ From the philosophical point of view, I argue, this is the most significant statement of Marx. The essence of Marxist philosophy is clearly reflected in this thesis, which can be considered to be the ground of his philosophical thought. This thesis, in my opinion, has made him the status of the philosopher of the philosophers. If we analyse this thesis, two important philosophical aspects of it would become evident. On the one hand, it is Marx's critique towards traditional philosophers through which he had been able to break the wall of philosophical traditions. On the other hand, his own philosophical thought is reflected in it, which has established Marxism as a practical or scientific philosophy (philosophy of praxis). 
Marx's principal academic training was in philosophy. He did his Doctoral thesis on Greek atomism entitled as the "Difference between the Democritean and Epicurean Philosophy of Nature". In this thesis what Marx said about the relation of matter to consciousness became the main theme of his materialism. As a matter of fact, this can be considered to be his first form of materialism, according to which man is not controlled or determined by any force other than himself, he is directed by his own will, i.e., he is free; God does not create man's fate, man himself is the creator of his own fate (he is the maker of himself). Marx was inspired by Epicurus' philosophy of nature that man is not mechanically determined by strict causal necessity, he has the power to transcend this causal chain, i.e. he is free (he enjoys freedom of will). He declared that it was philosophy, not God or religion, that could help man to survive, to provide him practical outlook of life. The function of philosophy, as he said, is to aware man of his consciousness, is to make him conscious about his freedom.

However, Marx's first philosophical thought was reflected in his School essay "On the choice of a profession of a young Man". In this essay he suggested that young man should work for the cause of humanity, he should choose such a profession which can serve for the whole mankind and dedicate his life for the cause of humanity. This reveals Marx's humanistic philosophy (philosophy of humanity) at the early stage of his life which has become the basis of his later (mature) philosophical thought.

Marx's early writings contain philosophical issues. But in his later (mature) thoughts he focused on political economy and the history of capitalism. It is said that there happens to be an epistemological break between Marx's early writings (mainly philosophical and psychological) and later writings (socio-political and economic). If so, then there seems to be two Marx- early Marx and later Marx. But that is not the case. There is no break in Marx's thoughts. His later writings are the continuation of his early works. Marx's early works are the ground of his later (mature) works. In other words, his philosophical ideas are the basis of his socio-political and economic thoughts.

There can be no doubt that Marx was a philosopher. However, it is more appropriate to describe him as a social, political and economic philosopher as well as a philosopher of social revolution. Marx was a philosopher in the sense that he was a systematic thinker and that he applied dialectics as a scientific method to understand man and society, to change society. He formulated a general outlook about human society. Marx was not a philosopher in the traditional sense: he was not concerned with the nature of reality, he was not a system builder, rather he had broken this tradition of philosophy.

Marx's socio-economic and political theories raise important philosophical questions about human nature and human aspirations, society and history. At the same time he gave some original answers to these questions. Marx did not write a comprehensive book on philosophy, neither did he provide any definite theory of philosophy. His critique of traditional philosophy entertain his philosophical outlook. We have to concentrate on his different writings to find out his philosophy.

Marx was a materialist in the sense that he formulated a materialist conception of history (historical materialism) according to which the basis of all social institutions and social consciousness is economic structure of society (material basis of society), and that social reality determines social consciousness. He was a dialectician in the sense that he 
applied dialectics as a definite method of philosophy to discover objective reality, to find out objective as well as internal contradiction of society. According to his (materialist) dialectics, nothing is static or unchangeable, nothing is final or eternal; everything changes and develops according to the law of dialectics (law of motion). Marx's materialism (historical materialism) is not a metaphysical theory of history like that of Hegel. It is an empirical hypothesis which is called a philosophy of history. His dialectics is not based on abstract concepts like Hegel's idealistic dialectics, rather it is based on concrete reality. In his words:

The premises from which we begin are not arbitary ones, but real premises from which abstraction can be made only in the imagination. They are the real individuals, their activity and their material conditions of life, ... These premises can thus be established in a purely empirical way. ${ }^{9}$

Marx bears the legacy of philosophical traditions, particularly of Hegel's dialectics and Feuerbach's materialism. He sees himself as heir to these two philosophical traditions. In many places he expressed his adherence to materialism and his opposition to idealism. He also distinguished his materialism from earlier materialism and his dialectics from that of Hegel. Marx rejected Feuerbach's mechanical method but accepted his materialism as the basis of his philosophical theory. $\mathrm{He}$ rejected Hegel's idealism but accepted his dialectics as a method of explaining change, motion and development of the objective world.

It would be appropriate to consider Marx as a philosopher of social revolution. Why there are changes in social life? Why society changes from one stage to another? How and why society develops. Why social revolution is inevitable in a classdivided society? How can social change be brought about?
These are certain basic philosophical questions about society and it was Marx who first gave original answers to these questions by applying his philosophy of dialectical and historical materialism. For him, social change can be brought about by social revolution, not by social reform or moral criticism. As he says:

...all forms and products of consciousness cannot be dissolved by mutual criticism, by revolution into selfconsciousness, or transformation into "apparitions", "specters", "whimsies", etc., but only by the practical overthrow of the actual social relations which gave rise to this idealist humbug; that not criticism but revolution is the driving force of history, also of religion, of philosophy and all other kind of theory. ${ }^{10}$

\section{Critique of Capitalism and Traditional Morality}

Marx's critique of capitalism in his different writings and his conception of communism in his Critique of the Gotha Programme entertain certain basic philosophical issues like objective contradiction, internal contradiction, exploitation, alienation, human nature, nature of human relations, justice, equality, distribution etc. He applied his materialism to society, particularly to capitalist society of his time. Naturally he analysed the nature of capitalist society and discovered the law of surplus value as the law of motion and development of capitalism. Two mutually contradictory classes exist in this society-the capitalist and the worker. The relation between the capitalist and the worker is a relation of exploitation and alienation. Capitalism is a society based on exploitation and economic inequality. The worker creates surplus value through his surplus labour and it is appropriated by the capitalist according to the law of capitalist economy (law of exchange). Not only that, the worker's labour power is mixed to commodity, he no longer belongs to it. The worker himself has 
been turned into a commodity. He loses his right to the commodity produced by his own labour power. This is how the worker loses his own self and suffers from the problem of alienation. He does not belong to his work, he does not enjoy his work.

Exploitation and alienation are the two main defects of capitalism. The root of these problems lies in the internal contradiction of the capitalist society. This is the contradiction between capital and labour, contradiction between the ownership of private property and the social character of production. Capitalist society is based on the ownership of private property. Ownership of private property causes economic disparity in this society and exploitation and alienation arise out of this disparity. Human relations in the capitalist society have been turned into a relations of buying and selling (of labour power), i.e., relations of transactions. The capitalists buy the labour-power of the workers, while the workers are forced to sell his laour-power. Thus human relations in this society have been turned into a commercial relations which is inhuman, and man's outlook has become shopkeepers' outlook.

The concepts of exploitation and alienation are centrally important in Marx. The presence of exploitation in a society provides a ground for moral criticism, that exploitation is wrong and exploiters are morally condemnable and hence it ought to be abolished. Exploitation can provide the exploited with a ground for taking individual or collective action against the system. The notion of exploitation carries a very specific meaning in Marx's thought. In his sense, a person is exploited if he performs more labour than is necessary to produce the goods that he consumes. Conversely, a person is an exploiter if he works fewer hours than are needed to sustain his consumption. For there to be exploiters, there must also be others who are exploited. But the converse need not be true. From the ethical point of view, exploitation cannot be a fundamental moral concept. One of the important causes of exploitation is the unequal distribution of wealth. Marx's critique of capitalism entertains the concept of exploitation in which the question of justice or injustice arises. It is unfair or unjust that some would be able to earn an income without working, while others who work would be derived of.

Marx located the phenomena of alienation at the level of individuals. By 'alienation' he meant the lack of selfrealization of the individuals. In his sense, alienation takes the form of an unsatisfied desire for self-realization, which could motivate people to create a society in which the desire could be satisfied. Marx prefered communism because it would abolish alienation. Under communism the self-realization of each and every individual would be possible i.e., each and every individual will live a good life (rich and active life). In Marx's thought, alienation simply means the absence of opportunities for self-realization. He placed exclusive emphasis on the lack of opportunities for self-realization in capitalism. He also emphasized that capitalism creates the material basis for communism in which the full and free self-realization of each and every individual becomes possible.

Alienation is related to exploitation in the sense that it adds to exploitation a belief on the part of the workers that capitalist has a legitimate claim on the surplus by virtue of his legitimate ownership of the means of production. The ownership is seen as legitimate appropriation of surplus. In his theory of alienation, Marx suggested that the capitalist exploitation alienated (separated) labour from the products. He condemned capitalism by virtue of an objective alienation. He 
believed that capitalism would be abolished because of this alienation. Marx's theory of exploitation in capital and his conception of communism in the Critique of the Gatha Programme entertain the idea of justice. On the one hand, capitalism is unjust in the sense that Marx treated capitalist extraction of surplus value as 'theft, embezzlement and robbery'. On the other hand, Marx's principle of distribution in communism entertains the conception of distributive justice. But Marx himself did not offer any specific theory of justice, neither he treated exploitation as a moral concept. He did not base his condemnation of capitalism on any moral concept (such as, justice).

Marx's critique of capitalism shows that he is a critique of traditional morality. He rejected morally based social criticism because it represents the interests of the ruling class and distorts social consciousness. Moral norms or ideals represent the interests of the ruling class as universal human interests. In this sense, they are distorted consciousness. According to historical materialism, moral norms are part of the 'ideological superstructure' of society. It is supported by Engels: "Man consciously or unconsciously, derive their ethical ideas in the last resort from the practical relations on which their class position is based-from the economic relations in which they carry on production and exchange." 11 Moral norms and beliefs, therefore, contribute to the basic economic tendencies in the society in which they are found. They only protect class-based social system and promote class interests. Marx attacked bourgoise morality because it arises from the capitalist system and protects the interests of the capitalist class. In his view, 'exploitation', 'alienation', 'oppression' and 'robbery' are the inherent nature of capitalist relations. As long as capitalist system exists, these features would be inevitable.
In Marx's view, moral norms and values of a society arise out of the economic relations belonging to its mode of production. Mode of production is, therefore, the basis for moral standards. Morality is not a blank tablet on which we can write whatever commandments seem best to us; it is made by people under definite socio-economic conditions. The very existence of moral concepts (right, justice, duty, virtue) is to be explained by the social functions they perform. Thus, Marx's materialist theory of history proposes to explain the specific content of moral norms by their correspondence to the prevailing mode of production. That is, valid moral standards (right and justice) consist in what corresponds to the prevailing mode of production.

All morality in a class divided society is, therefore, class morality and promotes the interests of the ruling class. All valid moral standards in capitalist society promotes the interests of the capitalist class. There cannot be any independent standard of morality transcending history. The capitalists live at the expense of the worker by means of private property. This is the law of capitalism. Whether capitalist exploitation should be abolished or not does not depend on whether it is just or unjust. It depends on whether capitalist social relations correspond to the prevailing mode of production. Traditionally philosophers are concerned with moral philosophy as a means for arriving at universal moral principles, abstract universal norms of right and wrong, good and bad. Marx was not concerned with this traditional form of moral philosophy, rather he was concerned with historical and social formations from which morality arises. He was interested in the socio-economic context within which morality arises. 


\section{Historical Materialism as Scientific Philosophy}

In The German Ideology Marx formulated his philosophy as the materialist conception of history (commonly known as historical materialism). His philosophy is called scientific in the sense that it provides a scientific theory of society, particularly of social change and development. Marx observed that the change and development of society took place in accordance with objective laws. The general theory of the motive force and the objective laws of social change is known as the materialist conception of history. Marx's materialism is a scientific philosophy in the sense that it explains society in its dialectical movement, i.e., in change, motion and development of society. He discovered the law of dialectics (law of motion) in explaining change, motion and development of the objective world, nature, society and thought. As the natural scientists discovered the law of transformation of nature, Marx discovered the law of transformation of society (from one stage to another). So, his materialism can be called scientific materialism by means of which he established a science of society. His scientific materialism is a way of explaining as well as solving the practical issues and problems of social life.

How does human society develop? What are its directive forces? Are the changes in society accidental or are they dictated by necessity, by objective laws? If society's development is causally conditioned, what is the chief cause, the foundations of social life? Social change is brought about by the conscious activities of the individuals. But the outcome of this activity and the conscious motives are conditioned by the laws of economic development which operate independently of the will or consciousness, i.e. objectively.

Marx brought about a revolution in social science. He freed social science from idealist conception of history and based it on materialist conception. According to him, history is made neither by great men like kings, military leaders or scholars (as the pre-Marxist sociologists thought) nor by divine will or God (as the pre-Marxist philosophers, particularly Hegel, observed). According to the idealist conception of history, society is ruled by divine will; God rules the world and the realization of his plans constitute world history. Marx freed history of human thought from idealism by formulating the principal postulate (basic premise) of historical materialism: 'Social being determines social consciousness'. ${ }^{12}$ Social being encompasses the material life of society, above all people's productive activity and the economic relations between them. Social consciousness includes the spiritual life of people, the ideas, theories and views which guide their ways of life and their activities (what they do).

Marx started with the premise that "life involves before everything else eating, drinking, housing, clothing and various other things. The first historical act is thus the production of the means to satisfy these needs, the production of material life itself". ${ }^{13}$ From this it follows that material production forms the foundation upon which the state, institutions, the legal conceptions, art and religious ideas have been evolved. This is Marx's materialist understanding of history which is considered to be scientific. According to this understanding, people are the real makers of history and their labour produce all the material wealth. This materialist conception of history or historical materialism is concerned with the study of society and the laws of its development. These laws are objective, i.e., independent of man's consciousness like the laws of nature. Laws of society are different from the laws of nature. While the laws of nature reflect the operations of blind, spontaneous forces, the laws of society are manifested through people's conscious activity in which they set themselves definite aims 
and work to achieve them. The laws of society are also studied by other social sciences (which study a certain group of social phenomena). But Marx's historical materialism studies the more general laws of social development. The development of society has unique features which distinguish social changes from natural events. The essential feature lies in the fact that society is composed of conscious human beings. Objective laws cannot be discovered in society as in nature. In nature everything is determined in accordance with natural laws, but in society, what happens is determined by people's conscious aims.

According to historical materialism, material (productive) relations are the determinative factors of social development. It is the totality of these production relations that constitutes the economic structure of society (the base). Each society has its own basis. No basis can appear until the corresponding material conditions, the productive forces are necessary for its birth. Once it arises, the basis plays a tremendous part in the life of society. The basis is important because it serves as the real foundation upon which the superstructure arises (political, legal, philosophical, moral and religious views). The superstructure also plays a very important role in social development. Arising on a definite economic basis, it ultimately expresses the attitude of people to this basis. Various ideas help people to influence the development of productive forces.

The superstructure is brought into being by the basis and is inseparably bound up with it. The superstructure depends on the basis. The basis of a class society has its contradictions. The economic basis of capitalism contains antagonism between the capitalist and the working class. The superstructure also contains contradictions. It includes the ideas and institutions of different classes. The ideas and institutions of the class which dominates economically prevail. Under capitalism the capitalist dominates economically so that capitalists ideas and institutions prevail and are used by them against the working class.

A close reading and observation will show that there are three guiding principles of Marx's historical materialism: 1) social development is regulated by objective laws (like science), 2) Views and institutions, political, cultural and ideological developments arise on the basis of the development of the material life of society and 3) the ideas and institutions which arise on the basis of conditions of material life play an active role in the development of the material life.

\section{Class Philosophy}

Marx brought about a revolution in the history of philosophical thoughts by providing an alternative view of philosophy. $\mathrm{He}$ observed that philosophy could not be isolated from society. In other words, there cannot be any philosophy in isolation from social reality. Thus he provided us with the idea of class philosophy. Philosophy emerged with the division of society into classes. In a class society, philosophy means the philosophy of a class. This class nature of philosophy became evident from the very day society was divided into classes. So, philosophy in a class divided society cannot be independent of class.

Now the question arises how did class and class philosophy emerge? Men had to go for work or production for survival and in this process working relations, i.e. relations of production among them were established. At one stage surplus value was created from relations of productions, ownership of private property from surplus value, class contradiction from ownership of private property and from there to class 
consciousness. As a result of class consciousness class philosophy (class outlook) emerged.

Every philosophy in a class society reflects a class outlook. For example, dialectical materialism reflects the outlook of the working class, while idealism and mechanical materialism expresses the outlook of the bourgeoise class. Philosophy is usually meant a world outlook which deals with the most general account of the nature of the world and man's place and destiny in it. Everybody has some kind of philosophy, and is influenced by some philosophical views even though they have never learned to discuss them, nor they have thought them out for themselves and formulate them.

When society is divided into classes, ever since the dissolution of the primitive communes (that is to say, throughout the entire period of human history to which the history of philosophy belongs), then the various views which arise in society always express the outlook of various classes. It may, therefore, be concluded that the various systems of the philosophers also always express class outlook. In fact, they are nothing but the systematic working out and theoretical formulation of class outlook, or of the ideology of definite classes. So, philosophy is and always has been class philosophy. Man do not and cannot think in isolation from society, and therefore from class relations and class interests. As a world outlook philosophy is an attempt to understand the world, mankind and man's place in the world. Such an outlook cannot be anything but the outlook of a class and the philosopher functions as the thinking representative of a class. Philosophers are not imported from some other planet, but are produced here on earth in existing class relations and class struggles. Therefore, there cannot any philosophy independent of class, or there is no philosophy which does not embody a class.

According to class philosophy, the individuals composing the ruling class possess consciousness. They rule as a class, they also rule as thinkers, as producers of ideas and regulate the production and distribution of the ideas of their age. So their ideas are the ruling ideas of the age. During Aristocracy the concepts honour, loyalty etc. were dominant, during bourgeois the concepts freedom, equality etc. were dominant. In Marx's words:

The idea of the ruling class is, in every age, the ruling ideas, i.e., the class which is the dominant material force in society is at the same time its dominant intellectual force. The class which has the means of material production at its disposal, consequently also means of mental production. The ruling ideas are nothing more than the ideal expression of the dominant material relations.... ${ }^{14}$

In The Communist Manifesto Marx and Engels declared that 'the history of all hitherto existing society is the history of class struggles, ${ }^{15}$ and formulated the law of class struggle as the objective law of social development. According to class philosophy, class struggle is the driving force of social development, the dialectics of society. Class philosophy is considered to be a scientific philosophy in the sense that it reveals the laws of dialectics, i.e. the laws of motion and development of society. Class antagonism is the objective contradiction of society, which reveals the laws of dialectics. Contradiction between capital and labour (the capitalist and the working class) is the internal contraction of the capitalist society. This contradiction, for Marx, can be solved through social revolution (proletarian or socialist revolution). 
According to historical materialism, class society reflects class philosophy. Marx formulated the philosophy of the working class as materialist world outlook. He regarded the modern working class as a conscious revolutionary class and provided them with class philosophy as a revolutionary philosophy. Class philosophy provides the working class with the idea of emancipation from class exploitation, from economic disparity. 'The emancipation of the working class must be the act of the working class itself'. ${ }^{16}$ The act is proletarian (or communist) revolution and the outlook is class outlook. The idea of emancipation implies the idea of an emancipating society (communist society), exploitation-free society. Class philosophy implies the idea of social revolution and a future communist society, a society based on humanity. Human emancipation, therefore, lies in the self emancipation of the working class. Thus, class philosophy appears to be a humanistic philosophy.

Marx considered the relations of production as the foundation of his class philosophy. Class, for him is a theoretical concept, not a descriptive category. In other words, Marx was concerned to uncover the underlying realities of society, not merely to describe how things appeared to be. An individual's class, in his view, is defined by the position he occupies in the relations of production. Thus, class is seen by him as a social relationship. The antagonistic social relations (relations of exploitation) are the heart of a class society. According to Marx, who is regularly compelled to sell his labour-power in order to live is a member of the working class.

Marx devoted his life to the cause of social revolution. He was committed to the philosophy of emancipation of man from exploitation, particularly of the working people from capitalist exploitation. He drew our attention because an understanding of his thought is essential for anyone who considers himself a social revolutionist, who wishes to do away with the exploitation and suffering that is built into the capitalist system whose law of motion he sought to uncover. For the questions which Marx raised are still alive. Marx provided a scientific analysis of the nature of capitalism which shows that capitalism is an exploitative social system and its internal contraction (between capital and labour) will lead either to socialism or to barbarism, and that the only hope for humanity lies in the working class overthrowing the capitalist state and replacing it with their own rule. So, it is not possible to understand the real nature of capitalism without reading the philosophy of Marx.

Capitalism has changed its form, but it has not changed its spots. It is still based on the exploitation of the working class, and liable to constant crisis. So, the conclusion Marx drew from this analysis that the working class would overthrow this system and would replace it with an exploitation-free (clasless) society, is still relevant in the world today. Socialist revolution is an imperative if we are to change the world in the grip of economic depression. To that extent, Marx's ideas are more relevant today than they were before. Capitalism has tightened its grip of iron on every portion of the world. Now, this is the time to free the world from the domination of world capitalism to save world humanity and the choice is between worker's power or the 'common ruination of the contending classes'between socialism or barbarism. Marx was always committed to the emancipation of the working class as well as to world humanity and conceived of the working class as the class whose own self-emancipation would also be the liberation of the rest of humanity. The socialist revolution to whose cause he devoted his life can only be the emancipation of the working 
class and the liberation of all the oppressed and exploited sections of society.

\section{Concluding Remarks}

Many of Marx's major works were jointly written with Engels. ${ }^{17}$ Engels was so closed to Marx's thoughts and activities that it would be impossible to understand Marx's thoughts without an understanding of Engels writings. Particularly, Marx's philosophical thoughts, which are scattered in his different writings, were first clarified, elucidated and formulated by Engels. So, Engel's writings can be taken as a reliable guide to Marx's thought. There are differences of opinion among the thinkers as to whether Engels works can be considered to be a real guide to Marx's own thought. However, understanding Marx through Engels eyes is nothing new, it began in Marx's own lifetime, and continue to exist still today. It is said that Engels distorted and oversimplified Marx's thought as a science which is inconsistent with Marx's own thought. However, Engels himself would never have claimed to be as great or an original thinker as Marx. 'Marx was a genius', he wrote, 'we others were at best talented.' Nevertheless, Engels made his own independent contribution to Marxism, both as a writer on scientific, philosophical and political subjects, and as populariser of Marx's ideas. He deserves to be studied in his own right. He rightly established Marxism as a scientific philosophy and based Marxist revolutionary politics on it. Marx's scientific theory and revolutionary politics (practice) go together, one cannot accept Marx's scientific theory and reject his revolutionary politics. ${ }^{18}$

In his speech at Marx's gravesides (1883), Engels proposed that Marx's immense achievements were to make two scientific discoveries which transformed our understanding of the social system. First, theory of historical materialism- 'just as Darwin discovered the law of organic nature, so Marx discovered the law of development of history'. Second, theory of surplus value-'Marx also discovered the special law of motion governing the present day capitalist mode of production....' Rudimentary versions of the theories of history and of economics begin to appear in some of Marx's early writings, composed in the 1840s. They were refined and developed throughout his entire working life and dominate his mature thought. ${ }^{19}$

Marx's early writings, though largely aimed at self clarification, are for us a treasure trove. Some of the most stimulating thoughts like alienation, economic analysis, theory of history are developed in these writings. Marx's early works are written in and before 1845 , but only a small proportion were published in his lifetime. Some important writings, such as The Paris Manuscripts and Economic and Philosophic Manuscripts of 1844 are a culmination of Marx's reading notes and subsequent reflection, apparently written in a state of great intellectual stimulation.

Do the works that Engels wrote after Marx died provide real guide to Marx's own thought? This question implies that the interpretation of Marx is still open. But we must start somewhere, and it is the traditional reading, i.e., reading Marx through Engels' eyes can be a reliable guide for us.

There is an important sense in which all of Marx's thought is still alive. Each one of Marx's major ideas is still very much worth studying. One reason for this is Marx's influence on the history of the twentieth century; his influence, in both theory and practice, is beyond measure. There are so many aspects of the current world, and current world of ideas, that we would be unable to grasp without understanding and appreciating Marx's 
thought. This would be enough to justify our close attention to Marx. But there is much more than this. Consider, for example, the great philosophers like Plato, Aristotle, Descartes, Hume and Kant. Why do we read them? It is not because they have proved, or established any firm results, but because they are worth reading. The value of the greatest philosophers lies in their power, depth, inventiveness, insight, originality and systematic vision. Their works could have been created only if they believed that they had just discovered truth, or were on the verge of doing so. But there are things much more interesting than truth. ${ }^{20}$ This way of understanding makes Marx's works worth reading and still alive.

Even if Marx's grandest theories ${ }^{21}$ may not be substantiated or proved to be true, his writings are so powerful that they cannot be abandoned to be unworthy. His work is full of insight and illumination. His major theories raise important philosophical questions about man and his hopes and aspirations, about society and history, which surely aspire his readers and provides food for thought for further thought (thought about thought). Marx also provided scientific (practical) solutions to the questions he raised. We may not agree with the solutions to the problems he identified but that does not make the problems go away; the problems remain exist still today and we have to go back to Marx for a clearl understanding of the nature of the problems. If philosophy is a thinking about thinking (rational thinking), Marx can be considered to be a thinker of the thinkers. It becomes evident when he says that reason has always existed but not always in a reasonable form. What he wanted to mean is a rational and scientific understanding of the world. So, we should read Marx to think about thinking, to get a rational and scientific understanding of the world for practical purpose, i.e for the purpose of changing the world.

\section{References}

1. Jon Elster, Making Sense of Marx, Cambridge University Press, Cambridge, 1985. For further discussion see-Haroon Rashid, Normative Marxism: Making Sense of Jon Elster's Marx, Jatiya Sahittya Prakash, Dhaka, 2017; LAP LMBERT Academic Publishing, Bean Basin, 2017.

2. Alex Callinicos, The Revolutionary Ideas of Karl Marx, Bookmarks, London, 1987, Introduction, P.7.

3. Marx-Engels, Selected Works, 3 Vols., Progress Publishers, Moscow, 1973, p.162, in Callinicos, The Revolutionary Ideas of Karl Marx.

4. Callinicos, The Revolutionary Ideas of Karl Marx, p. 8.

5. Ibid., pp. 8-9.

6. Ibid., p.9.

7. Bertrand Russell, History of Western Philosophy, Simon and Schuster, New York, 1945, pp. 782-790.

8. Karl Marx, "Thesis on Feuerbach", in Karl Marx and Frederick Engels, Selected Works in one Volume, Lawrence and Wishart, London, 1968, p.30.

9. Marx-Engles, The German Ideology, Progress Publishers, Moscow, 1976, pp. 36-37.

10. Ibid., 61.

11. Frederick Engels, Anti-Dühring, Foreign Languages Press, Peking, 1976, pp. 117-118.

12. Marx- Engels, The German Ideology, pp. 41-43.

13. Ibid., p. 47.

14. Ibid., p. 67.

15. Marx-Engels, "The Manifesto of the Communist Party", in Marx and Engels, Selected Works in one Volume, Lawrence and Wishart, London, 1968, p.35.

16. Ibid., Engels, Preface. 
17. Marx's lifelong friend, collaborator, and sometime patron.

18. That is the fundamental point about Marxism and it is, in Antonio Gramsci's words, the philosophy of practice. (Callinicos, The Revolutionary Ideas of Karl Marx, p.11)

19. Jonathon Wolff, Why Read Marx Today?, Oxford University Press, Oxford, 2003, pp. 9-10.

20. Ibid., pp. 100-101.

21. Theories of history (historical materialism) and economics (theory of surplus value) as proposed by Engels. 